\title{
Dampak Pendapatan Asli Daerah Terhadap Belanja Langsung Kabupaten Bandung Barat
}

\author{
${ }^{1}$ Chaereyranba Sholeh \\ ${ }^{\mathbf{1} A d m i n i s t r a s i ~ P u b l i k ~ F a k u l t a s ~ I l m u ~ S o s i a l ~ d a n ~ I l m u ~ P o l i t i k ~ U n i v e r s i t a s ~ P a d j a j a r a n ; ~ r e y r a n b a @ g m a i l . c o m ~}$
}

\begin{abstract}
This study has purpose to determine how the effect Regional Original Income to Direct Expenditures in West Bandung Regency for the period 2008-2017. This study uses the theory from Siregar (2015: 31) with method uses an associative type with a quantitative approach. This reseach useing secondary data with data collection techniques are literature studies (documentation) and field studies (observation). The population and sample of the study are the West Bandung Regency Regional Budget Realization Report 2008-2017. Statistical testing uses multiple regression analysis it where to determine how much influence the PAD component has on Direct Spending with a significance level of $\alpha=0.05$ using the t-test with SPSS 20 program. Significant value for the influence of independent variables regional tax, regional retribution, separated regional wealth management results and other legitimate PAD which is Regional Original Income simultaneously to Direct Expenditures of 0,000 $<0.05$ and calculated $F$ value of 68,983> F table of 4, 53. So that can be concluded of the independent variable namely Regional Original Income simultaneously influences the dependent variable of Direct Shopping in West Bandung Regency. The results is calculation of the determination coefficient and correlation coefficient that the effect of Regional Original Income on Direct Spending is 98.2\% with a correlation level of 0.982 which means it belongs to the category of very strong relationships. And the remaining $1.8 \%$ are influenced cause other variables not explained by the researcher.
\end{abstract}

Keywords: Regional Income, Direct Spending, Regional Financial Management Agency.

\section{Pendahuluan}

Siregar (2015:31) mengemukakan bahwa pendapatan asli daerah ialah sebuah penghasilan yang diperoleh suatu Pemerintahan di setiap Daerah yang berasal dari aset-aset wilayahnya sendiri yang kemudian dipungut menurut aturan hukum yang berlaku. Pendapatan asli daerah mencakup beberapa hal seperti hasil pengelolaan kekayaan daerah, pajak daerah, retribusi daerah, dan lain-lainya. Salah satu unsur dari pendapatan asli daerah tersebut ialah pajak daerah. Sari (2013:34) menjelaskan bahwa pajak ini merupakan suatu pemindahan modal atau asset dari unsur masyarakat untuk negara dalam bentuk kas yang diperuntukkan untuk mengelola dan mengatur beban belanja rutin, dan surplusnya digunakan untuk public saving (simpanan yang diperoleh hasil dari pajak yang dikurangi Bersama dengan pengeluaran pemerintah) yang merupakan sumber utama untuk membiayai investasi publik. Rahman (2005) menyebutkan bahwa terdapat beberapa pendapatan asli daerah lain yang absah seperti retribusi, jasa giro hasil penjualan aset daerah, serta penerimaan daerah di luar pajak. Aset tetap yang dapat dijual pemerintah daerah meliputi penjualan tanah, peralatan dan mesin, gedung dan bangunan, jalan, irigasi dan jaringan, serta penjualan aset tetap yang lainnya. Penerimaan jasa giro merupakan pendapatan yang diterima dari bank karena Pemerintah Daerah memiliki giro di bank tersebut. Penerimaan jasa giro meliputi penerimaan 
atas jasa giro kas daerah, jasa giro bendahara, dan jasa giro cadangan. Sedangkan pendapatan bunga meliputi pendapatan dari bunga deposito dan bunga dana bergulir.

Siregar (2015:31) mengelompokkan belanja daerah menjadi belanja tidak langsung dan belanja langsung. Pertama, yang dimaksud dengan belanja tidak langsung yakni dimana anggarannya tidak secara langsung bersentuhan pada program atau kegiatan. Hal ini diantaranya terbagi menjadi belanja bantuan sosial, belanja bagi hasil, bantuan keuangan belanja hibah, belanja pegawai, belanja tak terduga, belanja bunga, dan belanja subsidi. Kedua, yang dimaksud dengan belanja langsung adalah pengeluaran yang anggaranya berkaitan langsung atas pelaksanaan suatu program dan atau suatu kegiatan, diantaranya yaitu program kegiatan dan Belanja barang/jasa, Pegawai, dan modal.

Laporan Hasil Pemeriksaan (LHP) tahun 2018 yang dirancang oleh Badan Pemeriksaan Keuangan (BPK) menyebutkan bahwa Kabupaten Bandung Barat belum merincikan atau belum mendukung rincian dana sebesar Rp. 23,63 miliar yang digunakan untuk belanja barang dan jasa. Seharusnya Kabupaten Bandung Barat melaporkan dana sebesar Rp. 29,95 miliar yang digunakan untuk belanja pemeliharaan. BPK tidak memperoleh data dan informasi pada satuan kerja yang terkait, padahal pemerintah Kabupaten Bandung Barat secara administrasi sudah memiliki kebijakan dalam hal pencatatan, penyajian dan laporan belanja, tetapi hal ini masih belum diimplementasikan dengan baik. Begitupun pada belanja modal aset tetap lainnya tahun anggaran 2017, dana sebesar Rp. 4,95 miliar digunakan untuk pengadaan barang dan jasa. Pada kenyataannya pengadaan tersebut tidak dilaksanakan sesuai UU pengadaan barang dan jasa. Sehingga BPK tidak bisa mendapatkan bukti pemeriksaan yang cukup akurat. Tentang dampak dari pengadaan barang serta jasa yang tidak linear dengan ketentuan. Hal tersebut diduga dari pengelolaan keuangan daerah yang belum optimal dalam pelaksanaannya. Berikut data belanja langsung di Kabupaten Bandung Barat.

Tabel 1.1

Belanja Langsung Tahun Anggaran 2008-2017 Kabupaten Bandung Barat

\begin{tabular}{|l|l|l|l|}
\hline No & Tahun & \multicolumn{1}{|c|}{ Target } & Realisasi \\
\hline 1. & 2008 & Rp. 608.100.328.675,00 & Rp. 513.347.815.307,00 \\
\hline 2. & 2009 & Rp. 812.571.781.772,00 & Rp. 706.989.698.466,00 \\
\hline 3. & 2010 & Rp. $1.041 .024 .419 .749,00$ & Rp. 877.367.598.918,00 \\
\hline 4. & 2011 & Rp. 1.305.031.367.489,00 & Rp. 1.107.347.623.991,00 \\
\hline 5. & 2012 & Rp. 1.455.240.692.400,29 & Rp. 1.356.898.369.942,00 \\
\hline 6. & 2013 & Rp. 1.575.239.052.141,75 & Rp. 1.452.828.585.771,05 \\
\hline 7. & 2014 & Rp. 1.818.350.641.513,00 & Rp. 1.642.812.927.572,41 \\
\hline 8. & 2015 & Rp. 2.083.281.913.546,00 & Rp. 1.818.238.189.540,00 \\
\hline 9. & 2016 & Rp. 2.136.130.284.731,00 & Rp. 1.938.237.673.095,82 \\
\hline 10. & 2017 & Rp. 2.306.274.522.060,00 & Rp. 2.091.504.106.885,27 \\
\hline
\end{tabular}

Sumber: LHP Kabupaten Bandung Barat: Data di olah Peneliti 
Belanja Langsung Kabupaten Bandung Barat seperti terlihat pada tabel 1.1 perkembangannya selalu meningkat. Realisasi belanja langsung Kabupaten Bandung Barat meningkat di tahun 2012 yaitu sebesar 93,24\% tetapi pada tahun 2014 -2015 mengalami penurunan dari 90,35\% menjadi 87,28\%. Hal tersebut diduga Pendapatan Asli daerah di Kabupaten Bandung Barat masih rendah serta masih bergantung terhadap bantuan pemerintah pusat. Oleh karenanya, peneliti terdorong untuk melakukan penelitian dengan tujuan untuk menganalisis dampak pendapatan asli daerah terhadap belanja langsung di Badan Pengelolaan Keuangan Daerah Kabupaten Bandung Barat.

\section{Metode Penelitian}

Metode asosiatif digunakan dalam penelitian dengan melalui pendekatan kuantitatif. Dimana data dalam penelitian termasuk pada data primer yang diperoleh melalui pengamatan serta pencatatan di BPKD Kabupaten Bandung Barat dan data dalam penelitian berjenis sekunder yang berupa Laporan Pada periode 2008-2017 dari Realisasi Anggran Pendapatan dan Belanja Daerah di Kabupaten Bandung Barat. Dalam penelitian ini keseluruhan populasinya yakni Laporan Periode 2008-2017 dari Realisasi Anggaran Pendapatan serta Belanja Daerah di Kabupaten Bandung Barat periode dengan teknik sampel non probability sampling. Yang pada pengumpulan datanya menggunakan sudi pustaka dan studi lapangan (observasi, dokumentasi). Penelitian menggunakan alat analisis regresi linier berganda yang ditujukan dalam memahami pengaruh Pendapatan Asli Daerah dan Dana Alokasi Umum terhadap Belanja Daerah dengan bantuan olah data melalui software SPSS.

\section{Hasil Dan Pembahasan} 20.

Berikut hasil uji normalitas yang tercermin dalam grafik $p$ - $p$ plot menggunakan SPSS

\section{Gambar 3.1 Probability Plot Untuk Uji Normalitas}

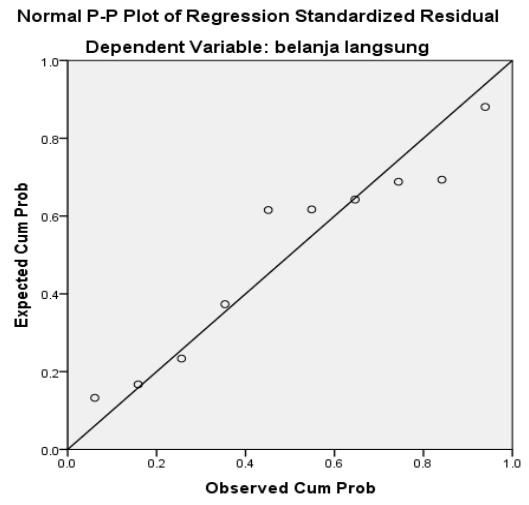

Sumber: Hasil output SPSS 20

Hasilnya terlihat data yang ada telah memenuhi syarat standard dari probability plot. Berikut merupakan hasil uji normalitas dengan menggunakan Kolmogorov-Smirnov yang tercermin dalam tabel: 
Tabel 3.1

Uji Normalitas Data Menggunakan Kolmogorov-Smirnov One-Sample Kolmogorov-Smirnov Test

\begin{tabular}{|c|c|c|c|c|c|c|}
\hline & & $\begin{array}{l}\text { pajak } \\
\text { daerah }\end{array}$ & $\begin{array}{l}\text { retribusi } \\
\text { daerah }\end{array}$ & $\begin{array}{c}\text { hasil } \\
\text { pengelolaan } \\
\text { daerah }\end{array}$ & $\begin{array}{l}\text { lain-lain } \\
\text { PAD }\end{array}$ & $\begin{array}{l}\text { Unstandardized } \\
\text { Residual }\end{array}$ \\
\hline \multicolumn{2}{|l|}{$\mathrm{N}$} & 10 & 10 & 10 & 10 & 10 \\
\hline \multirow[b]{2}{*}{ Normal Parameters ${ }^{\mathrm{a}, \mathrm{b}}$} & Mean & 2.8016 & 3.2010 & 1.9559 & 2.7748 & $0 \mathrm{E}-7$ \\
\hline & Std. Deviation & $\begin{array}{r}1.4502 \\
6\end{array}$ & .53073 & 2.72326 & 1.76400 & .08658964 \\
\hline \multirow{3}{*}{$\begin{array}{l}\text { Most Extreme } \\
\text { Differences }\end{array}$} & Absolute & .112 & .183 & .477 & .299 & .253 \\
\hline & Positive & .112 & .183 & .477 & .299 & .149 \\
\hline & Negative & -.100 & -.164 & -.323 & -.179 & -.253 \\
\hline \multicolumn{2}{|c|}{ Kolmogorov-Smirnov Z } & $\begin{array}{r}.353 \\
1.000\end{array}$ & $\begin{array}{l}.577 \\
.893\end{array}$ & $\begin{array}{r}1.508 \\
021\end{array}$ & .947 & .800 \\
\hline
\end{tabular}

Sumber: Hasil output SPSS Versi 20.

Tabel 3.2

\section{Hasil Uji Multikoliniarits}

Coefficients $^{\mathrm{a}}$

\begin{tabular}{|c|c|c|c|c|c|c|c|}
\hline \multirow[t]{2}{*}{ Model } & \multicolumn{2}{|c|}{$\begin{array}{l}\text { Unstandardized } \\
\text { Coefficients }\end{array}$} & \multirow{2}{*}{$\begin{array}{c}\text { Standardized } \\
\text { Coefficients } \\
\text { Beta }\end{array}$} & \multirow[t]{2}{*}{$\mathrm{t}$} & \multirow[t]{2}{*}{ Sig. } & \multicolumn{2}{|c|}{$\begin{array}{l}\text { Collinearity } \\
\text { Statistics }\end{array}$} \\
\hline & B & $\begin{array}{l}\text { Std. } \\
\text { Error }\end{array}$ & & & & $\begin{array}{c}\text { Toleranc } \\
\mathrm{e}\end{array}$ & VIF \\
\hline (Constant) & 1.120 & .374 & & 2.992 & .030 & & \\
\hline pajak daerah & .397 & .078 & .886 & 5.102 & .004 & .118 & 8.472 \\
\hline 1 retribusi daerah & .354 & .158 & .289 & 2.237 & .075 & .213 & 4.701 \\
\hline $\begin{array}{l}\text { hasil pengelolaan } \\
\text { daerah }\end{array}$ & .001 & .017 & .002 & .032 & .976 & .673 & 1.486 \\
\hline lain-lain PAD & -.066 & .050 & -.180 & -1.321 & .244 & .192 & 5.210 \\
\hline
\end{tabular}

a. belanja langsung

Dalam tabel diatas, nilai signifikansi 0.543 yang menunjukkan nilai $>0,05$ maka $\mathrm{H}_{0}$ ditolak artinya data residual distribusinya normal. Berikut hasil uji multikoliniaiaritas dimana masing-masing nilai tolerance variabel independen $>0.10$. Sementara nilai perhitungan variabel independen $<10$. Artinya tidak terjadi multikolinearitas pada data tersebut.

Hasil uji Autokorelasi yang dilakukan peneliti menghasilkan data sebagai berikut:

Tabel 3.3

Model Summary ${ }^{\mathrm{b}}$

\begin{tabular}{|l|r|r|r|r|r|}
\hline Model & \multicolumn{1}{|c|}{$\mathrm{R}$} & R Square & $\begin{array}{c}\text { Adjusted R } \\
\text { Square }\end{array}$ & $\begin{array}{c}\text { Std. Error of } \\
\text { the Estimate }\end{array}$ & $\begin{array}{c}\text { Durbin- } \\
\text { Watson }\end{array}$ \\
\hline 1 & $.991^{\mathrm{a}}$ & .982 & .968 & .11617 & 1.502 \\
\hline
\end{tabular}

a. Belanja langsung 


\section{Hasil Uji Autokorelasi}

Nilai Durbin Watson dalam tabel diata sebesar 1.502, pembanding menggunakan nilai signifikan 5\%. Jumlah sampel yang digunakan sebanyak 10. Karena nilai DWberada di antara dL sampai dengan dU (dL $0.3760<\mathrm{dW} 1.502<\mathrm{dU} 2.4137)$ maka hal tersebut menunjukkan tidak ada kesimpulan.

Hasil uji Heteroskedastisitas yang dilakukan peneliti terdapat data sebagai berikut:

\section{Gambar 3.2}

\section{Hasil Uji Heteroskedastisitas}

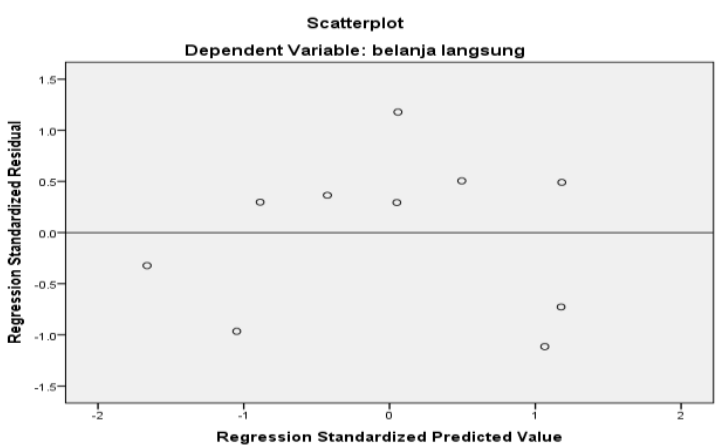

Terlihat dalam data diatas jika data menyebar pada garis nol dan tanpa membentuk pola tertentu. Maka data tersebut dapat dikatakan bebas heteroskedastisitas atau data homogen (homokedastisitas).

1. Perkembangan Pendapatan Asli Daerah di Kabupaten Bandung Barat periode 20082017

Berikut data PAD di Kabupaten Bandung Barat:

Tabel 3.4

Pendapatan Asli Daerah Tahun Anggaran 2008-2017 Kabupaten Bandung Barat

\begin{tabular}{|l|l|l|l|}
\hline No. & Tahun & \multicolumn{1}{|c|}{ Target } & Realisasi \\
\hline 1. & 2008 & Rp. $29.656 .248 .550,00$ & Rp. 33.617.474.326,00 \\
\hline 2. & 2009 & Rp. 36.511.537.438,00 & Rp. 39.964.363.945,00 \\
\hline 3. & 2010 & Rp. $43.047 .575 .305,00$ & Rp. 51.362.353.753,00 \\
\hline 4. & 2011 & Rp. $79.017 .129 .779,00$ & Rp. $94.606 .169 .067,00$ \\
\hline 5. & 2012 & Rp. $113.213 .153 .861,00$ & Rp. $136.241 .257 .300,00$ \\
\hline 6. & 2013 & Rp. 176.874.685.841,00 & Rp. 187.170.467.143,05 \\
\hline 7. & 2014 & Rp. 245.795.835.592,00 & Rp. 248.697.185.722,70 \\
\hline 8. & 2015 & Rp. 284.203.549.356,00 & Rp. 314.621.268.982,71 \\
\hline 9. & 2016 & Rp. 342.227.266.893,00 & Rp. 376.220.675.006,00 \\
\hline 10. & 2017 & Rp. 523.102.522.332,00 & Rp. 609.916.387.808,09 \\
\hline
\end{tabular}

Sumber: LHP Kabupaten Bandung Barat: Data Sudah di olah Peneliti 
Berdasarkan tabel diatas, lebih diperjelas oleh gambar berikut.

\section{Gambar 3.3}

\section{Grafik Perkembangan Pendapatan Asli Daerah}

Kabupaten Bandung Barat Periode 2008-2017

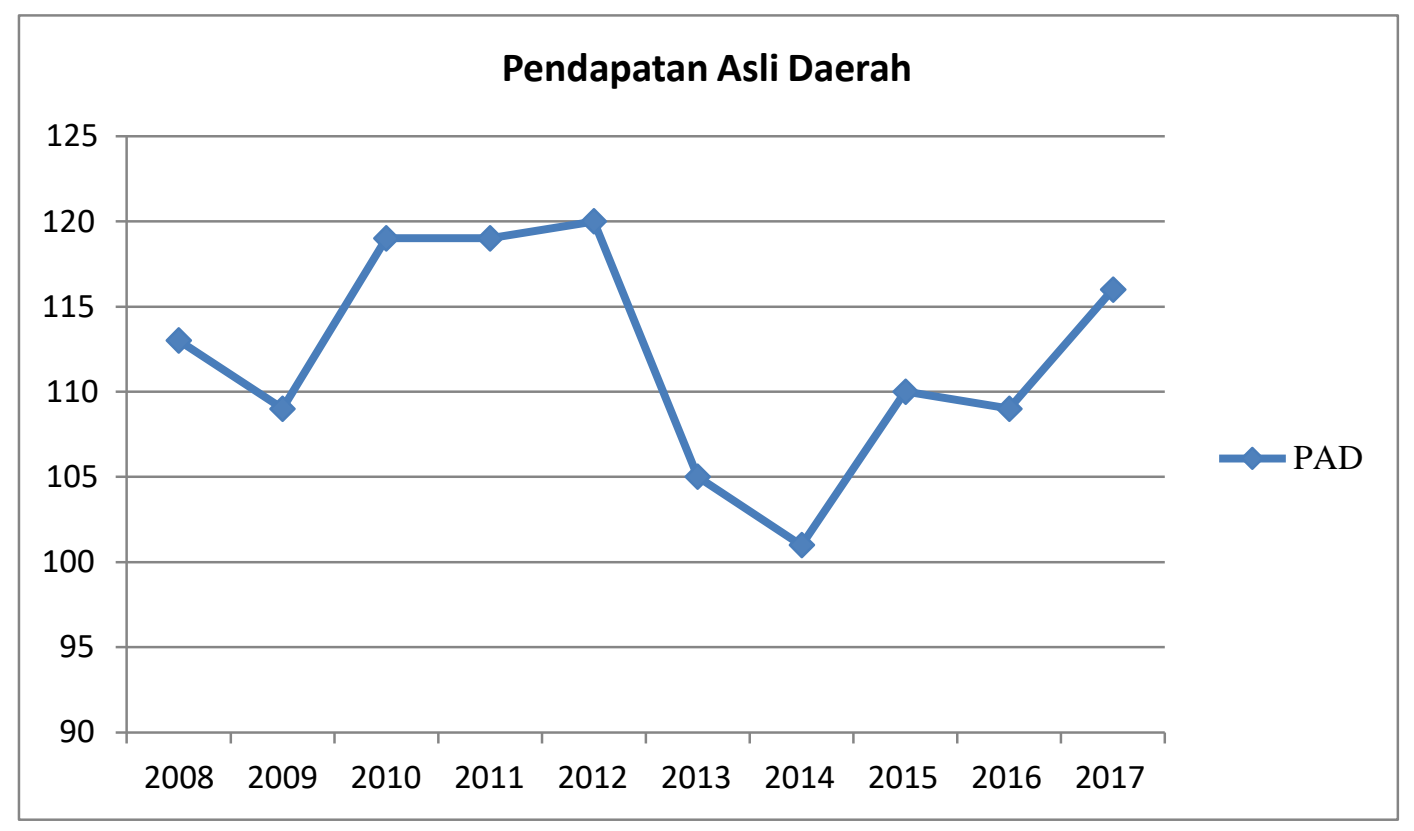

Berdasarkan tabel dan grafik diatas dapat diperhatikan bahwa Pendapatan Asli Daerah di pemerintah Kabupaten Bandung Barat mengalami kenaikan yang fluktuatif setiap tahunnya. Tahun 2012 yaitu sebesar 120,34 \% sedang pada tahun 2013 terjadi penurunan secara signifikan yaitu menjadi 105,82\% bahkan pada tahun 2014 Pendapatan Asli Daerahnya sebesar $101,18 \%$ pada tahun 2016 juga mengalami penurunan dari $110,70 \%$ menjadi $109,93 \%$.

\section{Perkembangan Belanja Langsung Tahun 2008-2017 Kabupaten Bandung Barat}

Setiap tahunnya Belanja Langsung yang dilakuikan terus meningkat. Akan tetapi relisasi mengenai perkembangannya belum terealisasikan dengan baik. 
Tabel 3.5

Belanja Langsung Tahun Anggaran 2008-2017

Kabupaten Bandung Barat

\begin{tabular}{|l|l|l|l|}
\hline No & Tahun & Target & Realisasi \\
\hline 1. & 2008 & Rp. $608.100 .328 .675,00$ & Rp. $513.347 .815 .307,00$ \\
\hline 2. & 2009 & Rp. $812.571 .781 .772,00$ & Rp. $706.989 .698 .466,00$ \\
\hline 3. & 2010 & Rp. $1.041 .024 .419 .749,00$ & Rp. $877.367 .598 .918,00$ \\
\hline 4. & 2011 & Rp. $1.305 .031 .367 .489,00$ & Rp. $1.107 .347 .623 .991,00$ \\
\hline 5. & 2012 & Rp. $1.455 .240 .692 .400,29$ & Rp. $1.356 .898 .369 .942,00$ \\
\hline 6. & 2013 & Rp. $1.575 .239 .052 .141,75$ & Rp. $1.452 .828 .585 .771,05$ \\
\hline 7. & 2014 & Rp. $1.818 .350 .641 .513,00$ & Rp. $1.642 .812 .927 .572,41$ \\
\hline 8. & 2015 & Rp. $2.083 .281 .913 .546,00$ & Rp. $1.818 .238 .189 .540,00$ \\
\hline 9. & 2016 & Rp. $2.136 .130 .284 .731,00$ & Rp. $1.938 .237 .673 .095,82$ \\
\hline 10. & 2017 & Rp. $2.306 .274 .522 .060,00$ & Rp. 2.091.504.106.885,27 \\
\hline
\end{tabular}

Sumber: LHP Kabupaten Bandung Barat: Data Sudah di olah Peneliti

Belanja Langsung di Kabupaten Bandung Barat sudah baik meskipun belum terealisasi $100 \%$ dan perkembangannya yang fluktuatif. Untuk lebih memberikan gambarannya, maka data tabel 4.5 diatas disajikan kedalam grafik berikut ini:

Gambar 3.4

Grafik Perkembangan dari 2008-2017 Belanja Langsung Kabupaten Bandung Barat

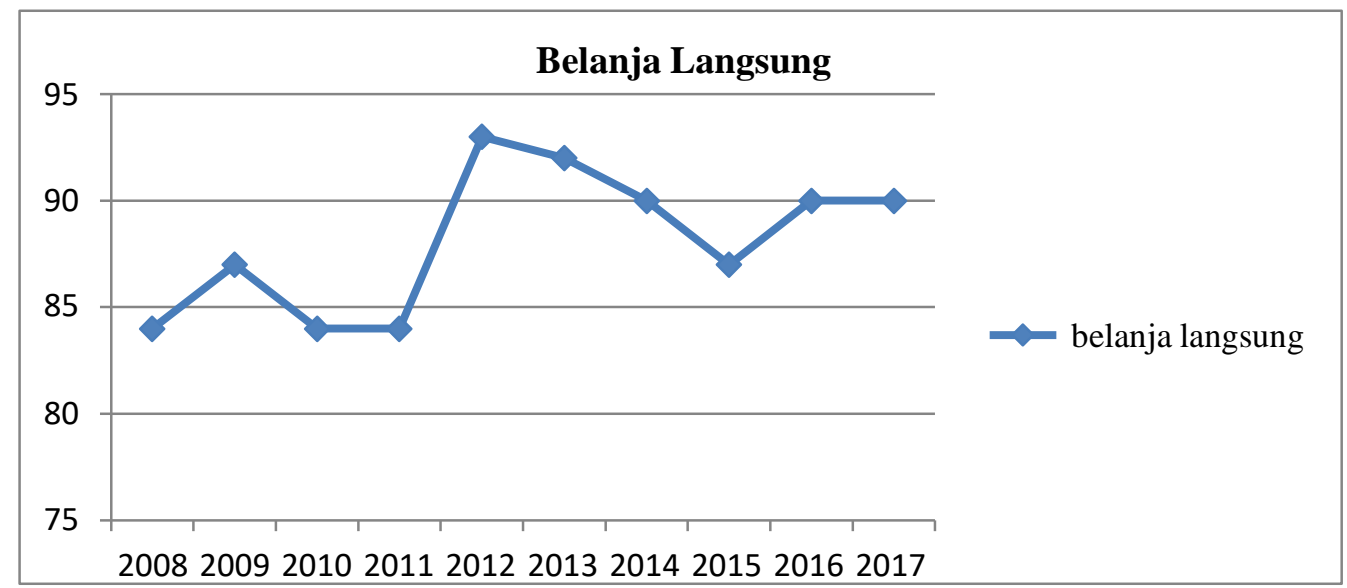

Pada grafik di atas terlihat bahwa belanja langsung pemerintah Kabupaten Bandung Barat meningkat pada setiap periodenya. Tahun 2013 belanja langsung menurun dari 93,24\% menjadi 92,23 \% , pada tahun 2014 dari 92,23\% menjadi 90,35\% dan pada tahun 2015 mengalami penurunan lagi menjadi $87,28 \%$. 


\section{Pengaruh PAD kepada Belanja Langsung di Kabupaten Bandung Barat}

Data perkembangan PAD dan belanja langsung Kabupaten Bandung Barat dapat dilihat sebagai berikut:

Tabel 3.6

Laporan Realisasi APBD Tahun Anggaran 2008-2017

Kabupaten Bandung Barat

\begin{tabular}{|l|l|l|}
\hline \multicolumn{1}{|c|}{ Tahun } & \multicolumn{1}{|c|}{ Pendapatan Asli Daerah } & \multicolumn{1}{c|}{ Belanja Langsung } \\
\hline 2008 & $33.617 .474 .326,00$ & $513.347 .815 .307,00$ \\
\hline 2009 & $39.964 .363 .945,00$ & $706.989 .698 .466,00$ \\
\hline 2010 & $51.362 .353 .753,00$ & $877.367 .598 .918,00$ \\
\hline 2011 & $94.606 .169 .067,00$ & $1.107 .347 .623 .991,00$ \\
\hline 2012 & $136.241 .257 .300,00$ & $1.356 .898 .369 .942,00$ \\
\hline 2013 & $187.170 .467 .143,05$ & $1.452 .828 .585 .771,05$ \\
\hline 2014 & $248.697 .185 .722,70$ & $1.642 .812 .927 .572,41$ \\
\hline 2015 & $314.621 .268 .982,71$ & $1.818 .238 .189 .540,00$ \\
\hline 2016 & $376.220 .675 .006,00$ & $1.938 .237 .673 .095,82$ \\
\hline 2017 & $609.916 .387 .808,09$ & $2.091 .504 .106 .885,27$ \\
\hline
\end{tabular}

Berikut statistik deskriptif PAD Kabupaten Bandung tahun 2008-2017 variabel dalam penelitian ini.

Tabel 3.7

Statistic Deskriptif Variabel Pendapatan Asli Daerah 2008-2017 dan Belanja Langsung pada 2008-2017 di Kabupaten Bandung Barat

Descriptive Statistics

\begin{tabular}{|c|c|c|c|c|c|c|c|c|}
\hline & \multirow{2}{*}{$\begin{array}{c}\mathrm{N} \\
\text { Statistic }\end{array}$} & \multirow{2}{*}{$\begin{array}{c}\text { Rang } \\
\text { Statistic }\end{array}$} & \multirow{2}{*}{$\begin{array}{l}\text { Min } \\
\text { Statistic }\end{array}$} & \multirow{2}{*}{$\begin{array}{c}\text { Max } \\
\text { Statistic }\end{array}$} & \multirow{2}{*}{$\begin{array}{c}\text { Sum } \\
\text { Statistic }\end{array}$} & \multicolumn{2}{|c|}{ Mean } & \multirow{2}{*}{$\begin{array}{c}\text { Std. Deviation } \\
\text { Statistic }\end{array}$} \\
\hline & & & & & & Statistic & Std. Error & \\
\hline $\begin{array}{l}\text { pajak } \\
\text { daerah }\end{array}$ & 10 & 4.58 & .39 & 4.97 & 28.02 & 2.8016 & .45861 & 1.45026 \\
\hline $\begin{array}{l}\text { retribusi } \\
\text { daerah }\end{array}$ & 10 & 1.40 & 2.55 & 3.95 & 32.01 & 3.2010 & .16783 & .53073 \\
\hline $\begin{array}{l}\text { hasil } \\
\text { pengelola } \\
\text { an daerah }\end{array}$ & 10 & 7.72 & .71 & 8.43 & 19.56 & 1.9559 & .86117 & 2.72326 \\
\hline $\begin{array}{l}\text { lain-lain } \\
\text { PAD }\end{array}$ & 10 & 5.65 & 1.16 & 6.81 & 27.75 & 2.7748 & .55783 & 1.76400 \\
\hline $\begin{array}{l}\text { belanja } \\
\text { langsung }\end{array}$ & 10 & 1.92 & 2.07 & 4.00 & 31.81 & 3.1813 & .20525 & .64906 \\
\hline $\begin{array}{l}\text { Valid N } \\
\text { (listwise) }\end{array}$ & 10 & & & & & & & \\
\hline
\end{tabular}


Berikut hasil uji analisis regresi linear berganda pada pengujian hipotesis:

Tabel 3.8

Hasil Uji Regresi Linear Berganda

\begin{tabular}{|l|c|c|c|c|c|}
\hline \multirow{2}{*}{ Model } & \multicolumn{2}{|c|}{$\begin{array}{c}\text { Unstandardized } \\
\text { Coefficients }\end{array}$} & $\begin{array}{c}\text { Standard } \\
\text { Coefficient }\end{array}$ & \multirow{2}{*}{ T } & Sig. \\
\cline { 2 - 4 } & B & Std. Error & Beta & \\
\hline
\end{tabular}

Tabel 3.9

\section{Hasil uji parsial}

\section{Coefficients $^{\mathrm{a}}$}

\begin{tabular}{|c|c|c|c|c|c|}
\hline \multirow[t]{2}{*}{ Model } & \multicolumn{2}{|c|}{$\begin{array}{l}\text { Unstandardized } \\
\text { Coefficients }\end{array}$} & \multirow{2}{*}{$\begin{array}{c}\text { Standardized } \\
\text { Coefficients } \\
\text { Beta }\end{array}$} & \multirow[t]{2}{*}{$\mathrm{T}$} & \multirow[t]{2}{*}{ Sig. } \\
\hline & B & $\begin{array}{l}\text { Std. } \\
\text { Error }\end{array}$ & & & \\
\hline (Constant) & 1.120 & .374 & & 2.992 & .030 \\
\hline pajak daerah & .397 & .078 & .886 & 5.102 & .004 \\
\hline 1 retribusi daerah & .354 & .158 & .289 & 2.237 & .075 \\
\hline hasil pengelolaan daerah & .001 & .017 & .002 & .032 & .976 \\
\hline lain-lain PAD & -.066 & .050 & -.180 & -1.321 & .244 \\
\hline
\end{tabular}

a. Dependent Variable: belanja langsung

\begin{tabular}{|l|c|c|c|c|c|}
\hline (Constant) & 1.120 & .374 & & 2.992 & .030 \\
pajak daerah & .397 & .078 & .886 & 5.102 & .004 \\
Redistribusi Daerah & .354 & .158 & .289 & 2.237 & .075 \\
Haasil Pengelolaan Daerah & .001 & .017 & .002 & .032 & .976 \\
PAD lain-lain yang sah & -.006 & .050 & -.180 & -1.321 & .224 \\
\hline
\end{tabular}

Belanja langsung: $1.120+0.397$ pajak daerah +0.354 retribusi daerah +0.001 hasil pengelolaan daerah yang dipisahkan - 0.066 PAD lain yang sah. berikut:

Pengujian parsial dilakukan yang dibantu dengan SPSS 20 mendapatkan hasil sebagai

1). Nilai signifikan pengaruh pajak daerah pada belanja langsung bernilai $0.004<0.05$ dengan nilai t hitung sebesar $5.102>2.571$ sehingga $\mathrm{H} 1$ diterima artinya ada pengaruh antara pajak daerah terhadap belanja langsung.

2). Nilai signifikan pengaruh retribusi daerah pada belanja daerah bernilai $0.075>0.05$ dan nilai t hitung sebesar $2.237<2.571$ sehingga $\mathrm{H} 1$ ditolak yang artinya pengaruh antar retribusi daerah terhadap belanja langsung tidak ada.

3). Nilai signifikan pengaruh hasil pengelolaan daerah yang dipisahkan bagi belanja daerah senilai $0.976>0.05$ dengan nilai thitung sebesar $0.032<2.571$ sehingga $\mathrm{H} 1$ ditolak artinya pengaruh antara hasil pengelolaan daerah yang dipisahkan terhadap belanja langsung tidak ada.

4). Nilai signifikan untuk pengaruh PAD lain yang sah terhadap belanja daerah $Y$ adalah senilai $0.244>0.05$ dengan nilai thitung senilai $-1.321<2.571$ sehingga $\mathrm{H} 1$ ditolak berarti tidak terdapat pengaruh antara PAD lain yang sah terhadap belanja langsung. 
5). Nilai signifikan untuk pengaruh Pendapatan Asli Daerah terhadap belanja daerah senilai $0.000<0.05$ dan nilai thitung sennilai $6.136>2.571$ sehingga H1 diterima berarti terdapat

Tabel 3.10

\section{Hasil uji parsial Pendapatan Asli Daerah}

Coefficients $^{\mathrm{a}}$

\begin{tabular}{|c|c|c|c|c|c|}
\hline \multirow[t]{2}{*}{ Model } & \multicolumn{2}{|c|}{ Unstandardized Coefficients } & \multirow{2}{*}{$\begin{array}{c}\text { Standardized Coefficients } \\
\text { Beta }\end{array}$} & \multirow[t]{2}{*}{$\mathrm{T}$} & \multirow[t]{2}{*}{ Sig. } \\
\hline & $\mathrm{B}$ & Std. Error & & & \\
\hline (Constant) & 1.914 & .226 & & 8.469 & .000 \\
\hline PAD & .428 & .070 & .908 & 6.136 & .000 \\
\hline
\end{tabular}

a. Dependent Variable: Belanja Langsung

pengaruh antara Pendapatan Asli Daerah terhadap belanja langsung.

Uji simultan mendapatkan hasil sebagaimana tertera berikut:

Tabel 3.11

\section{Hasil uji simultan}

\begin{tabular}{|ll|r|r|r|r|r|}
\hline Model & & Sum of Squares & Df & Mean Square & F & Sig. \\
\hline \multirow{3}{*}{1} & Regression & 3.724 & 4 & .931 & 68.983 & $.000^{\mathrm{b}}$ \\
& Residual & .067 & 5 & .013 & & \\
& Total & 3.791 & 9 & & & \\
\hline
\end{tabular}

a. Dependent Variable: belanja langsung

b. Predictors: (Constant), lain-lain PAD, hasil pengelolaan daerah, retribusi daerah, pajak daerah

Nilai signifikansi pengaruh variabel independen secara simultan terhadap Y sebesar $0.000<0.05$ dan nilai $F_{\text {hitung }}$ sebesar $68.983>F_{\text {tabel }}$ 4,53. Sehingga H5 diterima artinya pengaruh variabel independen secara simultan terhadap $\mathrm{Y}$ ada.

Dengan menggunakan spss 20 hasil pengujian Determinasi adalah sebagai berikut:

Tabel 3.12

\section{Hasil uji Koefisien Determinasi}

\begin{tabular}{|l|r|r|r|r|}
\hline Model & \multicolumn{5}{|c|}{ Model Summary $^{\mathbf{b}}$} \\
\hline 1 & $.991^{\mathrm{a}}$ & \multicolumn{1}{|c|}{ R Square } & Adjusted R Square & Std. Error of the Estimate \\
\hline
\end{tabular}

a. lain-lain PAD, hasil pengelolaan daerah, retribusi daerah, pajak daerah

b. belanja langsung

R Square senilai 0.982, hal berarti terdapat pengaruh mengenai variabel Independen yang simultan pada variabel Y senilai $98,2 \%$. Sedangkan sisa $(100 \%-98,2 \%=1,8 \%)$ dijelaskan variabel lain selain yang diteliti. 
Dari hasil pengujian yang dilakukan dapat dijelaskan secara rinci sebagai berikut:

1. Pengaruh Pajak Daerah pada Belanja Langsung di Kabupaten Bandung Barat.

Nilai signifikan untuk dampak pajak daerah terhadap belanja langsung adalah senilai $0.004<\alpha(0,05)$ dengan nilai thitung sebesar $5.102>t_{\text {tabel }} 2.571$ menunjukan pajak daerah berdampak secara signifikan pada belanja langsung yang dilakukan.

2. Retribusi Daerah pengaruhnya pada Belanja Langsung di Kabupaten Bandung Barat.

Nilai signifikan untuk dampak retribusi daerah pada belanja daerah adalah senilai $0.075>$ nilai $\alpha(0,05)$ serta Nilai signifikansi $t>\alpha$ yakni nilai $t_{\text {hitung }}$ sebesar $2.237<t_{\text {tabel }} 2.571$. Dengan ini retribusi daerah tidak berdampak secara signifikan kepada belanja langsung.

3. Hasil Pengelolaan Kekayaan Daerah yang dipisahkan terhadap Belanja Langsung di Kabupaten Bandung Barat.

Nilai signifikan untuk dampak hasil pengelolaan daerah yang dipisahkan pada belanja daerah adalah senilai $0.976>\alpha(0,05)$ dengan $t_{\text {hitung }}$ sebesar $0.032<t_{\text {tabel }}$ 2.571. Nilai signifikansi $\mathrm{t}>\alpha$ menunjukkan Hasil pengelolaan kekayaan daerah yang dipisahkan berdampak secara signifikan kepada belanja langsung.

4. PAD Lain-Lain yang sah terhadap Belanja Langsung di Kabupaten Bandung Barat.

Nilai signifikan untuk dampak PAD lain yang sah terhadap belanja daerah adalah $0.244>$ nilai $\alpha(0,05)$ dengan nilai $t_{\text {hitung }}$ senilai $-1.321<\mathrm{t}_{\text {tabel }} 2.571$. Nilai signifikansi $\mathrm{t}>\alpha$ $(0,05)$ memberikan petunjuk bahwa PAD lain yang sah tidak memberi dampak secara signifikan kepada belanja langsung.

5. Pendapatan Asli Daerah terhadap belanja langsung

Nilai signifikan uji parsial untuk dampak Pendapatan Asli Daerah terhadap Belanja Daerah senilai $0.000<0.05$ dan $t_{\text {hitung }}$ sebesar $6.136>t_{\text {tabel }}$ 2.571. Sehingga hal ini menunjukan H0 di tolak dan H1 diterima. Maka, ini berarti dampak antara Pendapatan Asli Daerah terhadap Belanja Langsung. Hal ini ditunjukkan juga dengan uji simultan yang nilai signifikannya sebesar 0.001 < nilai $\alpha(0,05)$. Nilai signifikansi $\mathrm{F}$ lebih besar dari $\alpha$ menunjukkan bahwa Pendapatan Asli Daerah berdampak secara signifikan kepada belanja langsung.

\section{Simpulan}

Apabila melihat pada hasil dan pembahasan penelitian, maka dapat disimpulkan bahwa pendapatan asli daerah secara simultan berdampak terhadap Belanja Langsung di Kabupaten Bandung Barat. Sedangkan berdasarkan pada hasil perhitungan koefisien determinasi dan koefisien korelasi, menunjukkan bahwa terdapat dampak pendapatan asli daerah terhadap Belanja langsung sebesar 98,2\% dengan tingkat korelasi sebesar 0,982. Itu artinya bahwa hal demikian termasuk dalam kategori hubungan yang sangat kuat. Sedangkan sisa sebesar 1,8\% dipengaruhi oleh variabel lain yang dalam penelitian ini tidak dijelaskan. 


\section{Referensi}

Darise, N. (2007). Akuntansi Keuangan Daerah. Penerbit PT. Indeks: Jakarta

Darmawan, D. (2013). Metode Penelitian Kuantitatif. Bandung: PT. Remaja Rosdakarya

Erlina, O.S.R., Rasdianto. 2015. Akuntansi Keuangan Daerah Berbasis Akrual. Jakarta: Salemba Empat.

Halim, A. (2007). Akuntansi Sektor Publik: Akuntansi Keuangan Daerah. Edisi 3. Salemba 4: Jakarta.

Mahmudi. (2016). Analisis Laporan Keuangan Pemerintah Daerah. Yogyakarta: UPP STIM YKPN.

Mardiasmo. (2002). Otonomi Dan Manajemen Keuangan Daerah. Penerbit Andi: Yogyakarta.

Rahayu, S.K. (2010). Perpajakan Indonesia. Yogyakarta: Graha Pustaka

Rahman, H. (2005). Pendapatan Asli Daerah. Jakarta: Arifgosita

Ratmono, D., Mahfud, S. (2015). Akuntansi Keuangan Daerah Berbasis Akrual. Yogyakarta: STIM YKPN-Yogyakarta.

Rosdini, Dini. 2008. Akuntansi Pembiayaan dan Transaksi Nonkas bagi Pemerintah Daerah. Bandung: Fakultas Ekonomi Universitas Padjadjaran.

Sanusi, Anwar. 2013. Metodologi Penelitian Bisnis. Jakarta: Salemba Empat.

Sari, D. (2013). Konsep Dasar Perpajakan. Bandung: PT Refika Adimata

Siregar, B. (2015). Akuntansi Sektor Publik (Akuntansi Keuangan Pemerintah Daerah Berbasis Akrual). Edisi Pertama.Yogyakarta:Unit Penerbit dan Percetakan Sekolah Tinggi Ilmu Manajemen YKPN

Sugiyono. (2013). Statistika Untuk Penelitian. Bandung: Alfabeta.

Sunarto. (2005). Pajak dan Retribusi Daerah. Yogyakarta: Amus Yogyakarta dan Citra Pustaka Yogyakarta.

Sutedi, A. (2010). Hukum Perizinan Dalam Sektor Pelayanan Publik. (cet.ke-1, Jakarta: Sinar Grafika

Syarifin, P., Jubaedah, D. (2005). Hukum Pemerintahan Daerah. Bandung: Pustaka Bani Quraisy.

Ulum, I. (2008). Akuntansi Sektor Publik. Malang: UMM Press.

Umar, H. (2005). Metode Penelitian. Jakarta: Salemba Empat

Waluyo. (2005). Perpajakan Indonesia. Jakarta: Salemba Empat 